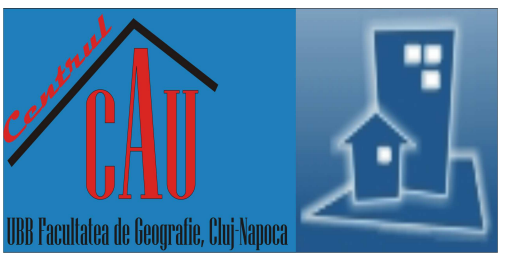

\title{
Delineation of the Urban Influence Area Using the Multi-Criteria Assessment Method. The Case of Focşani City, Romania
}

\author{
Florentina-Cristina MERCIU**, Irina MARVU1, Oana Bianca ILIESCU1, George-Laurențiu \\ MERCIU' \\ ${ }^{*}$ Corresponding author \\ ${ }^{1}$ University of Bucharest, Faculty of Geography, Department of Human and Economic Geography, Bucharest, ROMANIA \\ ${ }^{2}$ University of Bucharest, Faculty of Geography, Department of Geomorphology, Pedology and Geomatics, Bucharest, ROMANIA \\ E-mail: cristina.merciu@geo.unibuc.ro, irina.mavru@yahoo.com, iliescubiancao5@yahoo.ro,george.merciu@geo.unibuc.ro
} DOI: 10.24193/JSSP.2019.1.02

https://doi.org/10.24193/JSSP.2019.1.02

K e y w o r d s: urban influence area, connectivity, urban-rural interface, territorial ties, regional development

\begin{abstract}
A B S T RA C T
The delineation of urban influence area has been analysed since the beginning of the $19^{\text {th }}$ century and has also attracted the interest of specialists in the current period, as a result of the socioeconomic changes that have a strong impact on the evolution of urban agglomerations. The importance of delineating influence areas results from the need to quantify the polarization degree of cities and the extent to which they influence adjacent territories. The aim of this study is to delineate the influence area of Focşani city, a secondranked urban centre and the seat of Vrancea county. The main hypothesis of this paper is that Focșani city is able to structure the urban and rural surrounding areas through the influence and power of attraction it exerts on them. Authors use two comparative methods to delineate the influence area both theoretically (applying the Reilly-Converse formula) and empirically on the basis of a dynamic and comprehensive analysis using a set of key criteria: transport systems, economic, demographic, social and cultural aspects. Based on specific indicators for each of these criteria, authors analyse several data series (2002-2017) to identify transport areas, social and cultural areas, supply area, etc. Individualizing each influence area and overlapping them using GIS techniques led to the delineation of the influence area of Focșani city. Taking into consideration the intensity of territorial relationships established between Focşani city and the other settlements within Vrancea County, we identified that the influence area could be divided into three areas of primary, secondary and tertiary importance. The comparative analysis of the different indicators revealed, as a main conclusion, that Focşani city has influence on the entire territory of Vrancea County.
\end{abstract}

\section{INTRODUCTION}

Between the urban centres and the territories situated in their proximity, different spatial ties of economic (Ianoş, 1987; Pintilii, 2008; Drăghici, 2012; Peptenatu et al., 2012; Ali and Varshney, 2012), social (Drăghici et al., 2011; Ali and Varshney, 2012; Catană and Baltălungă, 2012; Ianoş et al., 2014; Randolph and
Tice, 2017), and cultural (Tănasă, 1998; Pintilii, 2008; Drăghici, 2012; Merciu et al., 2012; Ianoş et al., 2014; Nicula et al., 2017) nature are established. They are further strengthened due to the polarizing centre constantly demanding space for economic activities, recreation and habitation (Ianoş, 1987; Drăghici et al., 2011; Peptenatu et al., 2012). Urban areas provide goods and services that also attract the population from 
the adjacent area to the city. The evolution of these territorial links has become even more complex and determines the individualization of particular spaces under the influence of large cities as structures with a specific set of socioeconomic dynamics that are considered emergent (Peptenatu et al., 2012).

Establishing the urban influence area is important due to the need to quantify the degree of polarization of a certain city and the way it propagates influence in the adjacent territory. The intensity of territorial ties established between the urban centres and adjacent areas is correlated with the size of the polarizing city, its rank and activities (Surd, 2003; Rusu, 2007; Surd and Păcurar, 2010).

The role of small and medium-sized towns in ensuring the connection between urban and rural areas is also quite significant. Towns represent key elements of the spatial and functional structure in every country (Bański et al., 2016) and become micro-regional urban centres (Servillo et al., 2014), ensuring administrative, services and trade functions for the inhabitants of the surrounding countryside (Bański et al., 2016).

A large city with a complex functional character offers multiple facilities, exerting influence on the population situated at a greater distances from the urban polarizing centre (Ianoş, 1987; Wang, 2001; Ali and Varshney, 2012; Koushik et al., 2015).

Another term, semantically close to that of the urban influence area, is the metropolitan territory, which is defined as the area polarized by the large cities. Metropolitan areas also known as "engines of development" (De Lucca, 2016), where social and economic innovation takes place due to the polarizing capacity of large cities, considered the 'backbone' of urban system settlements (Sobolev, 2015). Large cities, entitled 'growth poles', are associated with several priorities at the European level such as sustaining balanced territorial development or development inside the metropolitan areas (Benedek, 2016).

Urban polarization generates large population concentrations within and around large cities through peri-urbanization (Iordan, 1973; Cusin et al., 2016) or suburbanization processes (Walks, 2007; Cepoiu, 2009; Cîrnu, 2012; Dumitrache et al., 2016; Kristóf, 2018), triggering increased interregional differences, a marked urban-rural separation and thus many demographic and socioeconomic consequences (Madzevic et al., 2013; Dumitrache et al., 2016; Vlad Şandru et al., 2017; Kristóf, 2018; Vasárus et al., 2018). Over time, the urban development process, also related to social dynamics generates changes in the socio-spatial structure of cities and metropolitan areas (Modai-Snir and van Ham, 2018) and a gradual decrease of socioeconomic development along the 'centreperiphery' line (Sobolev, 2015; Surd et al., 2015).

Over the last 60 years urbanization has occurred more forcefully than ever in the human history
(Scott and Storper, 2015) and it has changed boundaries, morphologies and scales of human settlements (Vigano et al., 2017). Aggressive urbanization rendered the increase of artificial land (Petrişor, 2012; Lois González et al., 2016) by the contraction of agricultural land (Ianoş et al., 2010; Petrișor et al., 2010; Zitti et al., 2015; Hama and Petrişor, 2018), by deforestation (Ianoş et al., 2010; Zitti et al., 2015; Verma et al., 2017; Niţă et al., 2018), impacting water bodies and natural parks (Ianoş et al., 2010; Zitti et al., 2015), and generating complex process environmental conflicts (Ianoş et al., 2010; Petrişor et al., 2010; Ianoş et al., 2017).

The importance of the geographic research on the relationships between cities and their adjacent areas was first referenced at the beginning of the $20^{\text {th }}$ century, by defining the term of urban influence area. The term "umland" was defined as the economic domain including areas immediately around an inner city (Allix, 1922). Later, several researchers have broadened its meaning, now corresponding to areas immediately around a city, closely linked economically and culturally to it (Jucu, 2012; Onea, 2016).

Another similar term is "hinterland", whose original meaning, in the opinion of several geographers, referred exclusively to ports (Van Cleef, 1941). Another meaning of the word is delimited in terms of the valley of the river on which the port is located. The third significance attributed to this term is that it is a tributary port area (Van Cleef, 1941; Smailes, 1947) or the area that has commercial links with a port (Van Cleef, 1941). In urban geography however, "hinterland" has been defined as the area surrounding a town and which is served by it (Smailes, 1947).

For the first time in scientific literature, the notion of influence area was used by H. Bobeck (1927), who emphasized that geographic analysis should be focused not only on the city itself but also on the relationships with the surrounding territory (Pintilii, 2008).

Similar concepts used in the geographic literature are "sphere of influence", named "rural neighbourhood", and "catchment area" or "urban field" (Smailes, 1947). For instance, Smailes (1947) opts for the term "urban field" and proposes two ways of establishing specific areas: first, by surveying the relationships between rural population and nearby urban centres, and secondly based on the range of food supplies delivery.

Before Christaller's central place theory, the American geographer W.J. Reilly (1929), published mathematical formulas to theoretically identify the attraction areas of urban centres (Rusu and Man, 2006; Pintilii, 2008; Catană and Baltălungă), establishing an analogy between the commercial attraction of two cities and Newton's universal attraction theory: "two cities attract buyers from the rural surrounding areas 
directly proportional to their population and inversely proportional to the square of the distance between them" (Rusu and Man, 2006). The mathematical equation elaborated by Reilly was later improved by Converse (1935), who established an easier calculation method known as the Reilly-Converse gravitational model. Converse added a breaking point between the two cities, $\mathrm{A}$ and $\mathrm{B}$, located on the $\mathrm{AB}$ straight line, where the number of those who go shopping in one city is equal to the number of those who go shopping in the other city (Rusu and Man, 2006).

Several studies have been geared towards defining the real urban influence area as the support space for the development of an urban centre. In a geographical monograph on Călărași city, Romania, Mihăilescu used the terms "daily supply area", "periodical supply area" and "remote drainage area"; the first two terms were set according to the frequency to which fruits and vegetables were delivered to the urban population, whilst the third term represented the grain storage area (Pintilii, 2008). Another related term used for urban influence area is "maintenance" area (Pintilii, 2008). This term is similar to the supply area, too.

Later, several authors defined the "supply area" as the city's fruit and vegetable supply area centre (Vigano et al., 2017), a strip of land where vegetable crops predominate. M. Tigoiu analysed Constanța city, Romania, and identified three areas of influence, namely: the "current supply area", the "area of labour supply" and the area of "cultural and political influences" (Pintilii, 2008).

Much more, Ianoș (1987) elaborated a study on the urban influence area, in which he defined the theory of the systems in a complex manner and from a new perspective. The author considered the city and influence area as two subsystems with close relationships of "different types, directions and intensities", which ensured the city's existence and prosperity. The same author defined the urban influence area as "adjacent or complementary space".

According to the provisions of Law no 351/2001, a more recent definition reflects many similarities to the one previously formulated by I. Ianoș. The influence area is currently defined as "including the territory that surrounds an urban centre and which is directly influenced by the city's evolution and by the inter-conditioning and cooperative relationships that develop among economic activities, the supply of agrifood products, access to social and commercial facilities, construction of infrastructure elements and facilities for relaxation, recreation and tourism" (Law no 351/2001). Also, the same law specifies that the dimensions of the influence area are directly related to the size and functions of the polarizing urban centre.

In recent decades, valuable contributions have been made in delineating the urban influence area, taking into account several variables, such as: functions and size of the city in the urban hierarchy of a country (Ianoş, 1987; Surd, 2003; Rusu and Man, 2006; Surd and Păcurar, 2010; Koushik et al., 2015) time spent for travelling to the nearest town (Vojkan, 2013; Mutabdzija, 2016) and geographical position (Ianoş, 1987; Rusu and Man, 2006; Surd and Pacurar, 2010). Subsequently, various studies have proposed to delimit the influence area based on empirical analysis using new criteria, considering several aspects, namely: economic (Ianoş, 1987; Ghelfi and Parker, 1997; Nang et al., 2014), social and cultural (Pintilii, 2008; Tănasă, 1998; Merciu et al., 2012; Ianoş et al., 2014; Koushik et al., 2015; Randolph and Tice, 2017), political (Ianoş, 1987; Nicula et al., 2017), and demographic (Landré and Håkansson, 2013; Mutabdzija, 2016; Živanović and Tošić, 2017; Kristóf, 2018; Vasárus et al., 2018).

The purpose of this study is to define the influence area of Focşani city using the multi-criteria assessment method. The main working hypothesis was that Focşani city can represent an urban agglomeration by exploiting resources offered by a functional territorial support structure.

\section{THEORY AND METHODOLOGY}

First, the authors applied the Reilly-Converse formula in order to identify the theoretical influence area of Focşani city using the ArcGIS software. In the latest studies, several authors delineated the theoretical urban influence areas in Romania for cities and towns in Banat (Rusu, 2007), Bucharest (Pintilii, 2008), Ploiești (Catană and Baltălungă, 2012) and Caransebeș (Onea, 2016). At international level, cities in Central China have also been examined (Nang et al., 2014). These authors have considered two basic elements in their methodology. First, beside the city for which the influence area is calculated, other cities and towns from the same county are selected, plus other county seats and cities of the neighbouring counties. So as to delineate the theoretical influence areas, all cities and towns have to be ranked by demographic size. The second important element considered is the distance between cities and towns. Secondly, authors used the multi-criteria assessment method selected from the scientific literature for marking the real urban influence. The methodology employed consisted of the following steps: establish relevant indicators, consider a number of key criteria based on economic, transport, demographic, social-cultural considerations; compare the list of indicators with statistical records in order to complete it; and data collection, processing, interpretation and mapping. Data were collected freely from the National Institute of Statistics (Tempo online database) and Ministry of Education. To obtain relevant and comparable results, we used data for the period 2002-2017. 
One of the main criteria selected is the convergence of transport systems, which allows for the delineation of the urban influence area according to the daily movements of population for different purposes such as economic, educational, recreational activities, etc. (Ianoş, 1987; Wang, 2001; Vojkan, 2013; Kraft et al., 2014). Therefore, in establishing boundaries both road and rail transport routes and their degree of accessibility are considered, through which a close connection between the city and the settlements located inside the influence area is facilitated. How transport network is organized in the influence area is reflected in the development level of both the city and the polarized neighbouring area.

Transport flows represent a very good indicator because they show the complexity of the spatial relationships established between the city and its polarized area (Ali and Varshney, 2012; Kraft et al., 2014; Yao et al., 2018). These relationships and the length of their propagation in the territory reflect the spatial extension of the influence area (Ianoş, 1987; Wang et al., 2014) and can configure its shape (Pintilii, 2008; Drăghici, 2012; Koushik et al., 2015; Yao et al., 2018).

Taking into account the transport criteria, we created maps of the frequency of road and train passenger transport linking Focșani with the settlements in its support area.

Another key criterion is the economic one, reflecting the most intense relations between a city and its influence area, considering the commercial attraction, city's attractiveness of labour resources by establishing the geographical relationship between workplaces and workers' homes (Smailes, 1947; Landré and Håkansson, 2013) and the relationship between the agricultural sector and the agri-food needs of the urban centre through the agricultural production in the adjacent area of the city (Smailes, 1947; Ianoş, 1987; Pintilii, 2008; Drăghici, 2012). This production is oriented to the requirements and needs of the city. Using information on the supply flows, market-areas can be mapped (Smailes, 1947).

Based on economic criteria, we elaborated a map of agricultural units that serve the population of Focşani city with agri-food products.

The demographic criteria refer to the complex relationships - in terms of intensity and frequency established between the city and the adjacent area. The city influences the socio-professional structure of the inhabitants in the nearby area, through selective attraction, but also by imposing economic activities (Ianoş, 1987). Commuting patterns provide data on important daily movements in urban areas, their surroundings and the linkages between them. By processing the raw data of commuting flows, these patterns can be further analysed from the perspective of their relationship with local economic development
(Landré and Håkansson, 2013). The daily territorial mobility for economic activities results from workforce shortage in the city, but also from the newly established residential function of the settlements in the urban influence area.

Several indicators were used in different studies to reflect the changes in population due to demographic relationships established between the city and its influence area, e.g. growth rate (Merciu et al., 2012; Ianoş et al., 2014; Živanović and Tošić, 2017; Vasárus et al., 2018), net migration rate (Pintilii, 2008; Drăghici, 2012; Kristóf, 2018; Vasárus et al., 2018), commuting flows (Živanović and Tošić, 2017; Landré and Håkansson, 2013), employment (Pintilii, 2008; Drăghici, 2012; Ianoş et al., 2014), share of people by level of education (Živanović and Tošić, 2017; Kristóf, 2018). Some authors use the commuting flows generated by a predefined employment urban centre as an indicator to delineate the urban influence area of Göteborg city (Landré and Håkansson, 2013). Considering the commuting flows generated by lucrative activities as an important indicator, we named the support area that provides human resources as the labour market area.

The lack of statistical data on daily territorial mobility for economic activities and employment in the influence area of Focşani city imposed a limit to the use of only two demographic indicators: growth rate and net migration rate.

The socio-cultural criteria are defined by several elements: power of school and university attractiveness exercised by a city on the surrounding area (Smailes, 1947; Ianoş, 1987, Tănasă, 1998; Pintiii, 2008; Merciu et al., 2012; Koushik et al., 2015), cultural institutions, sometimes specialized health services (Smailes, 1947; Tănasă, 1998; Pintilii, 2008; Drăghici, 2012, Merciu et al., 2012), social assistance, legal services, the existence of local radio and television stations (Tănasă, 1998), circulation of newspapers (Smailes, 1947), etc.

Regarding socio-cultural facilities, some settlements cannot have all types of social utilities, but from a functional point of view, settlement are analysed from the perspective of concentration of available social facilities (Koushik et al., 2015).

To delineate the cultural-education area of Focşani, the number of secondary school students coming from the communes and towns in the surrounding area to attend high schools in the polarizing city was used. This indicator has been previously used by different authors in order to establish the cultural and educational area of some cities in Romania: Botoşani (Tănasă, 1998), Bucharest (Pintilii, 2008), Râmnicu Vâlcea (Drăghici, 2012) and Reşița (Merciu et al., 2012).

Based on specific indicators for each of these criteria, we individualized each type of influence area, 


\section{Delineation of the Urban Influence Area Using the Multi-Criteria Assessment Method. The Case of Focşani City, Romania \\ Journal Settlements and Spatial Planning, vol. 10, no. 1 (2019) 13-28}

and their representation and overlapping using the ArcGIS software led to the general territorial delineation of the urban influence area of Focşani city.

\section{RESULTS AND DISCUSSION}

\subsection{The theoretical influence area Focşani city}

In determining the limits of the theoretical influence area of Focșani, the Reilly-Converse formula was applied. Central places of other urban centres, located in Vrancea County, were taken into consideration. By applying the Reilly-Converse formula, in a double sense, first for Focşani city in relation to the other towns in Vrancea County and then for each of those towns in relation to Focşani, authors conceptualized a synthetic and integrated analysis of the urban system (network) of the county. At the same time, we calculated the attraction areas for the county seats of the neighbouring counties (Buzău, Brăila, Galați, and Bacău) in order to highlight whether they exert any level of attraction upon certain parts of the analysed area. The urban centres selected as central places were ranked, according to population size, as follows: Galați as first-ranked urban centre, the other county seats (Brăila, Buzău, Bacău, and Focşani) as second-ranked cities, Bârlad as third-ranked city, Râmnicu Sărat and Onești as fourth-ranked cities. Rank 5 corresponds to the small towns of Odobești, Panciu, Mărășești and Adjud, located in Vrancea County. Authors elaborated two maps to calculate the attraction areas of Focşani and other cities and towns to achieve a comparative result.

The attraction area of Galați, classified as firstranked and included in the category of large cities, goes beyond the borders of Galați County, extending to the four counties nearby (Vaslui, Brăila, Vrancea, and Buzău) (Fig. 1).

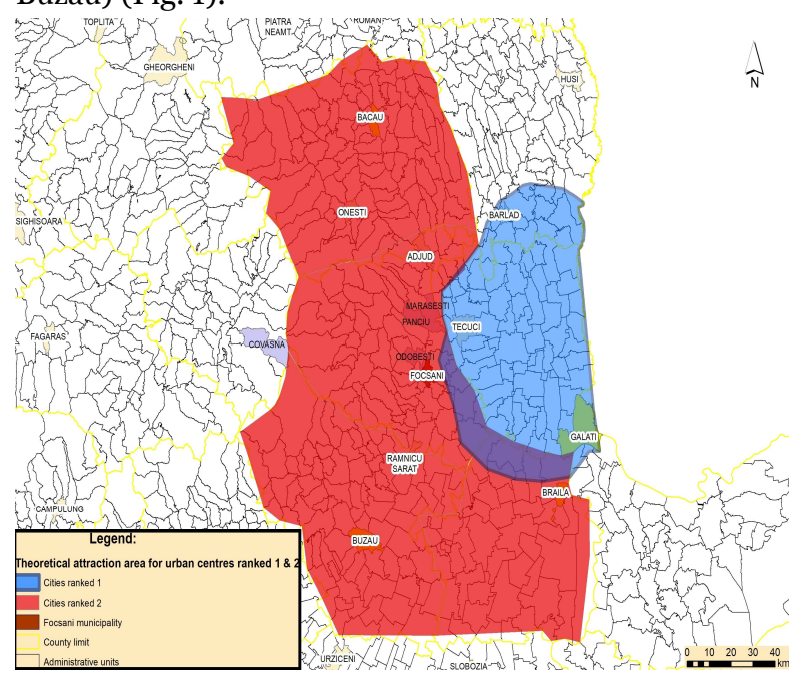

Fig. 1. The theoretical influence area according to the Reilly-Converse formula for the first and second ranked urban centres.
From the economic point of view, Galaţi city is better developed compared to the other county residences analysed, being in direct competition with them. Galați is an economic metropolitan development centre, having a number of strengths: it is one of the largest commercial traffic hubs in Romania, connected to the main European communication corridors, by road, by river, via the Rhine-Danube TEN-T corridor (Galați is the second most important port of Romania and railroads ensure the transfer from the European track to the one used in the former Soviet countries. Another very important aspect is that the traditional industrial branches of the city are still functional. In parallel, the service sector has developed, especially the (IT industry and education through continuous diversification), which can contribute to attracting labour resources at county and regional level.

The theoretical influence area of Focşani includes a large polarization area that covers Vrancea County entirely (Fig. 1). Results show the presence of only four other small towns in Vrancea County with a spatial distribution that indicates their concentration along road E85 and in the northern part of Focşani, while the rest of the county (the western and southern parts) has no town. The small towns of Vrancea County have limited influence area due to their rank and also because of the high degree of polarization of Focşani city.

Not considering the geographical discontinuities at the territorial level is a limitation of this theory. We note the lower degree of polarization in the western part of Vrancea County due to low accessibility determined by low transport network density, in this case the political and administrative relationships prevailing. The west of Vrancea County is important because it represents a recreational support area for the urban population in the county seat, but also from other towns.

In the case of the other second-ranked cities (Buzău, Brăila, and Bacău) all of them representing county seats, we may notice that the limits between the attraction areas of these cities resemble very much straight lines, due to the similarity of their administrative functions. Regarding the polarizing capacity of the other county seats, it is observed that they are at relatively large distances from Focşani city, which determines strong connections with the neighbouring rural area.

The attraction areas have different shapes, with the urban centre located in the focal point closer to the neighbouring larger city. The main feature is that the the highest ranked city within the settlement system always has a more extensive attraction area which, in fact, includes all the others. Thus, it can be estimated that all the settlements under study have their attraction area included within the influence area of an upper-ranked settlement (Fig. 2). 


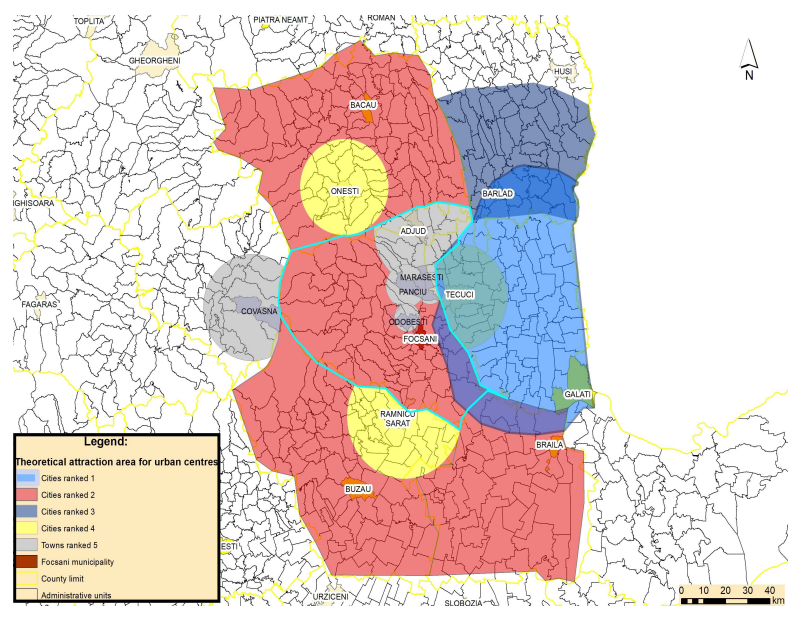

Fig. 2. The theoretical influence area according to the Reilly-Converse formula for urban centres ranked 3, 4, 5 .

Bârlad town was included in the category of third-ranked cities, whose urban influence area developed in the central and southern parts of Vaslui County, not exceeding the county boundaries as results from the application of the Reilly-Converse formula show.

In the case of all fourth-ranked cities the attraction areas are included within those of the county seats. Also, the demographic size of Tecuci and Râmnicu Sărat towns and the small distance between them and Focşani, do not allow the extension of the influence area of the two cities beyond the border of the county in which they are located (Fig. 3).

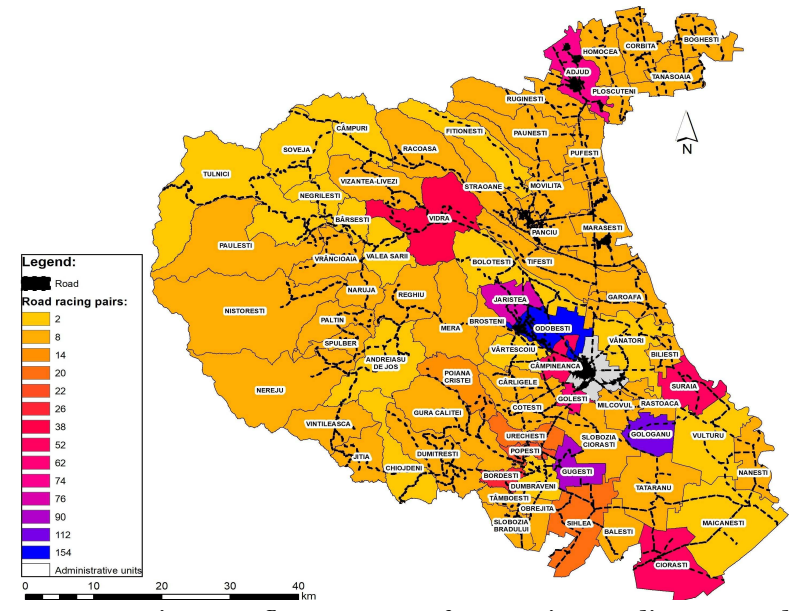
transport.

Fig. 3. Influence area of Focşani according to road

Small towns of Odobești, Panciu, Mărășești, and Adjud are classified as fifth-ranked urban centres. The influence area of the towns of Odobești, Panciu, and Mărășești, which are located closer to the county seat, is limited to their administrative territories and a few other settlements around them. We also note that in their case the influence areas overlap and interpenetrate (Fig. 2).

On the other hand, Adjud town has a larger influence area in comparison with the other small towns in Vrancea County. Adjud is ranked as municipality 18 with a population twice as large as other towns and it is located at a greater distance from Focşani. Thus, the nearby rural settlements gravitate around it. The influence area of Adjud partly overlaps (the southern part) the attraction area of Mărășești town.

\subsection{The real influence area of Focşani city}

\subsubsection{Influence area of transports}

Transports play a particularly important role in establishing urban influence areas. For the most precise delineation, both road transports (by the number of round trips by bus and minibus) and railway transports connecting Focşani and the settlements in its adjacent space were taken into consideration.

In order to indicate the borders of the influence area of the road transports, we took into account the number of transports two-way connections from Focşani to the neighbouring settlements of both state-owned companies (Focşani-Odobeşti, FocşaniCâmpeneanca, Focşani-Goleşti) and private companies that ensure the extension of transport connection beyond the first neighbouring settlements around Focşani: Faraoanele, Vărsătura, Jariştea, SatuNou, Boloteşti, Țifeşti, Scânteia, Popeşti, Urecheşti, Găgeşti, etc (Fig. 3).

Authors collected data related to the road trips operated by state and private transport companies by accessing Focșani central bus station (Autogara Nord Focşani). The main connecting road, E85 (DN2), crosses the studied area from south to north. This road connects Bucharest to Focşani, continuing outside the administrative boundary of Vrancea County. It is noticed that settlements located along the E85 road register the highest number of trips per day (Odobeşti and Goleşti) (Fig. 3).

Another important road is DN 23, connecting Focşani to Brăila, through the communes of Răstoaca, Vulturu and Măicăneşti. DN 2A is a road of secondary importance that crosses the western part of the influence area of Focşani and connects it to the town of Târgu Secuiesc.

For a more precise delineation of the influence area of Focşani according to transportation network , we included settlements served by the main transport routes which have a small number of trips per day, or which are in the proximity of the transport routes (Coteşti, Cârligele, Boloteşti, Soveja, etc.). These trips serve persons who carry out their economic or administrative activities in the county seat and also students who live in the influence area and attend high school in Focşani.

The number of buses/minibuses per day for each settlement situated in the influence area was analysed to obtain the average number of trips per year on the main roads, which may vary from 40,320 to 46,200 . For the roads of secondary importance the 
average number of trips per year varies from 32,400 to 12,210. The main railway transport axis is the $500 \mathrm{~km}$ mainline (Bucharest-Bacău-Suceava), which follows the south-north direction, along which there are mostly 9 pairs of trains (thus, 18 train trips)providing the connection between Focşani and settlements in the eastern and south-eastern part of its influence area (Pufeşti, Garoafa, Slobozia-Ciorăşti, Gugeşti, and Sihlea) (Fig. 4).

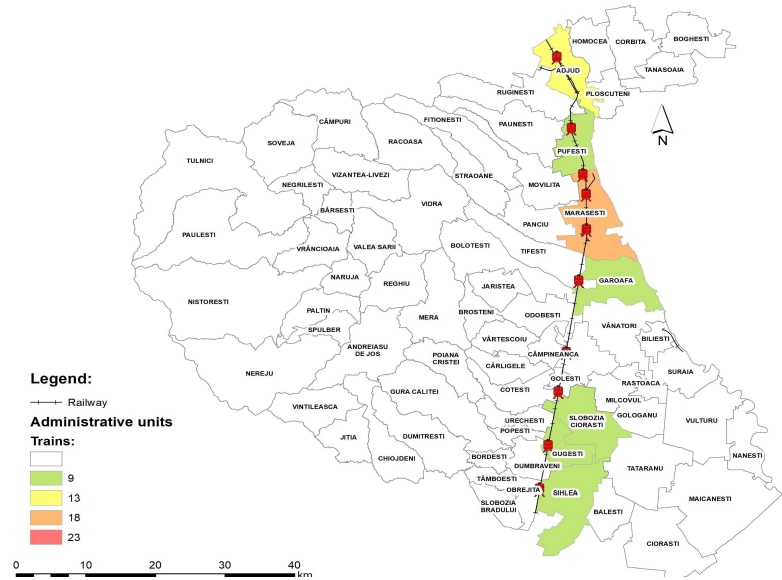
railway transports.

Fig. 4. Influence area of Focşani city according to

The railway transport in Vrancea County is represented only by the inter-regional trains, providing service for a smaller number of settlements compared to the more-dense road connections at county level.

According to Law no. 351/2001(2001), Focșani city fulfils the criteria related to direct access to two major communication systems.

\subsubsection{Demographic indicators}

The demographic criteria consisted of growth rate and net migration rate indicators, calculated for three years (2002, 2011, and 2017). Population growth rate was calculated for two time intervals in order to observe the changes registered in urban and rural areas. Data analysis was performed considering the general socioeconomic context, and the role played by Focşani city in the differentiated dynamics of the number of inhabitants and the demographic structures of the settlements in its influence area.

The analysis of demographic indicators in recent years reflects a general trend of population decrease, in urban and rural areas, with a few exceptions.

The highest positive values of the population growth rate in Vrancea county, in the period 20022011, are recorded in 27 communes, half of which are located around Focşani (Goleşti 25.08\%, Răstoaca 12.94\%, Vârteşcoiu 11.68\%, Coteşti 8.72\%, Bilieşti 8.45\%, Broşteni 8.29\%, Garoafa 5.93\%, Jariştea 2.71\%) (Fig. 5).

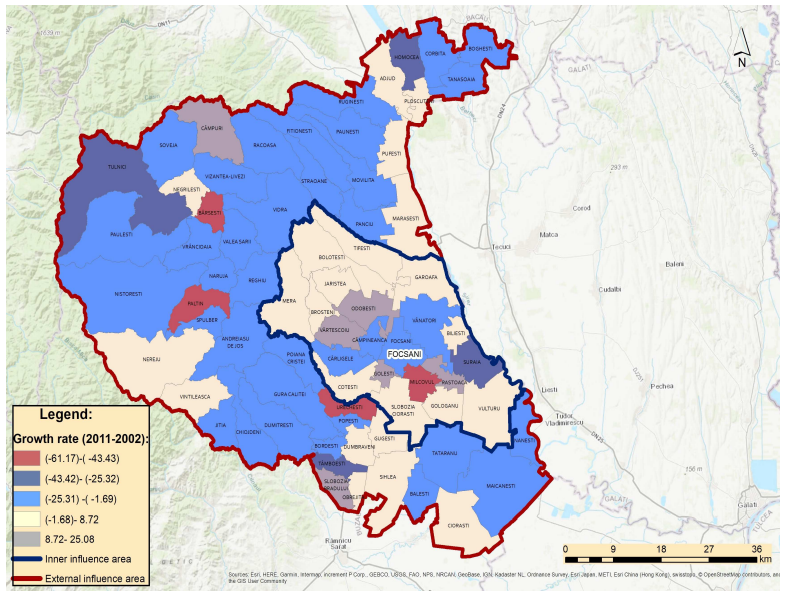

Fig. 5. Growth rate in the influence area of Focșani city (2002-2011) (source: The National Institute of Statistics, modified).

The average values (between $-25.31 \%$ and $1.69 \%)$ are specific to half of the total number of communes (51) in Vrancea County, these being located mainly in the northern, north-eastern and northwestern parts of the county (Fiționești -7.28\%, Soveja 10.25\%, Nistoreşti -10.25\%). These communes, especially those located in mountainous area (western part of the county) are affected by the demographic ageing. Few communes (8) recorded high negative values in: Milcov (-61.17\%), Urecheşti (-50.52\%), Bârseşti (-57.76\%), Paltin (-43.43\%), Tulnici (-35.33\%), Homocea (-25.32\%), Tâmboieşti (-30.74\%) and Suraia $(-27 \%)$. In the case of urban areas, Odobeşti town registered the highest population growth (12.25\%), followed by Mărășești (4.82\%) and Adjud with a slight increase of the population (0.12\%). Panciu town recorded a slight population decrease (-2.27\%). Compared with the previous interval, between 20112017, there weas a smaller number of communes in Vrancea County that registered high positive values, more specifically, only those located in the surrounding area of Focşani city: Goleşti (10.93\%) and Vârteşcoiu (5.82\%) (Fig. 6).

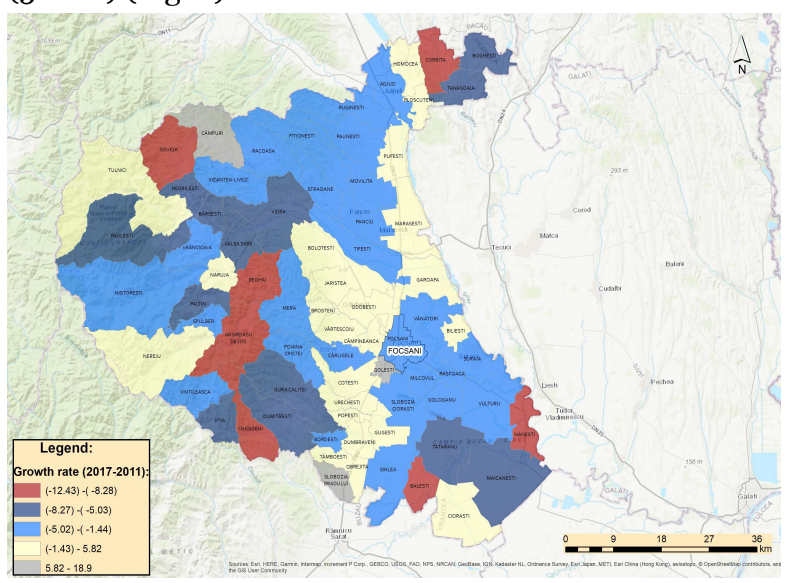

Fig. 6. Growth rate in the influence area of Focșani city (2011-2017) (source: The National Institute of Statistics, modified). 
However, these positive values were lower compared to those recorded in the period 2002-2011. The number of communes showing negative values increased. They are concentrated in the northern, western and south-eastern parts of the county and it can be estimated that the highest negative values are much lower compared to those recorded in the previous interval.

Most of the settlements that registered population growth during the period 2002-2017 are situated around the county seat and three other towns. Thus, communes located in the first three rings of settlements around Focşani city and the town of Odobești can be considered parts of the inner influence area, within which the most intense territorial ties are established in terms of offering most of the human and material resources.

In terms of mobility, Vrancea County registers the lowest value in the South-East Development Region (Integrated Strategy for Sustainable Development of Focşani City, 2016). In terms of internal migration, urban population that changed residence settled mostly in rural areas.

This situation explains the low population increase registered by settlements around Focșani city during the period 2002-2011, as a result of the low intensity of the suburbanization of the county seat. These population flows would be considerably reduced over the period 2011-2017.

The analysis of net migration in 2002 highlights, on the one hand, the communes located around Focşani city that recorded very low negative values of the net migration rate or which are in stagnation (equal values of departures and arrivals) (e. g. Gologanu, Răstoaca, Vânători, Câmpineanca) (Fig. 7).

On the other hand, a large number of communes lost population due to migration, and they are mainly concentrated in the northern part of Vrancea County (Fig. 7). Odobeşti town is the only settlement registering positive values of the net migration rate (28.25\%).

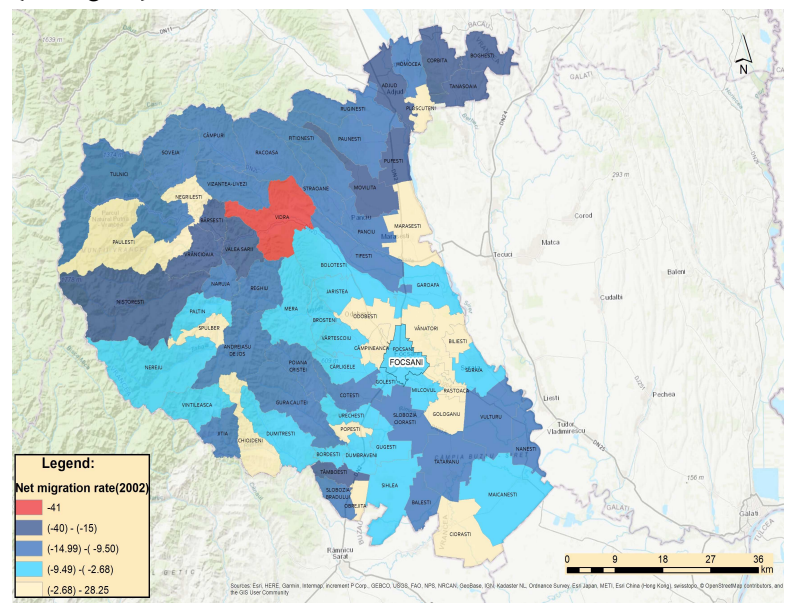

Fig. 7. Net migration rate in the influence area of Focșani city (2002) (edited by authors based on data provided by the National Institute of Statistics).
Most of the communes located in the internal influence area of Focşani city register a slower decrease in the number of population due to migration in 2011 (Fig. 8). Settlements located in the external functional area register higher negative values. Population decline is correlated to a low level of economic development, which also leads to the reorientation of population to large urban centres outside the county or even opting to migrate abroad.

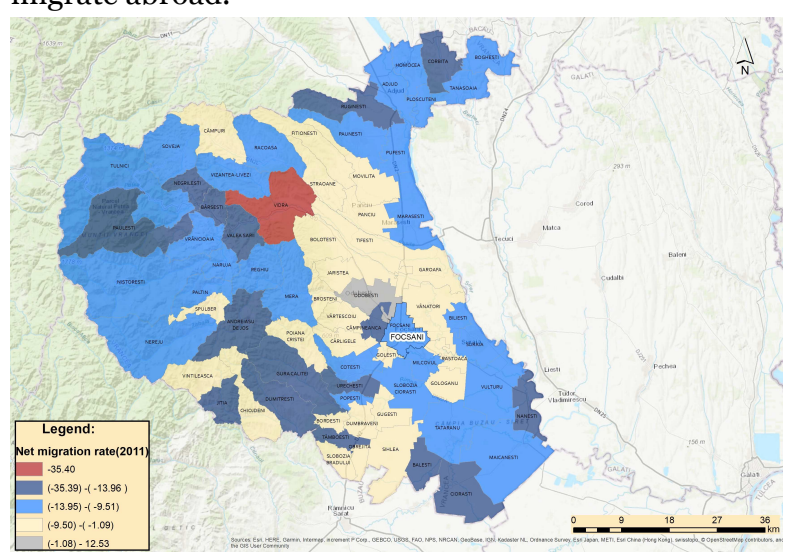

Fig. 8. Net migration rate in the influence area of Focşani city (2011) (edited by authors based on data provided by the National Institute of Statistics).

There is a general trend of population decrease in several settlements in Vrancea County in 2017, which reflects the relationship between demographic behaviour and the level of socioeconomic development changes (Fig. 9).

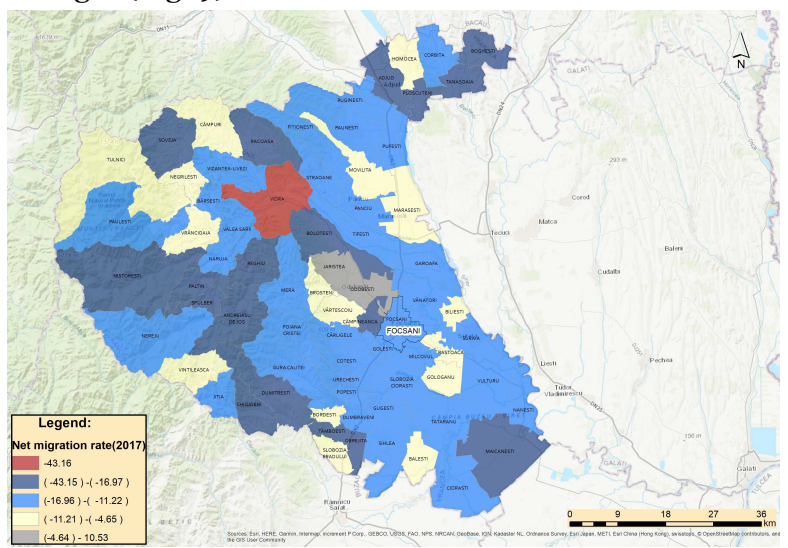

Fig. 9. Net migration rate in the influence area of Focşani city (2017) (edited by authors based on data provided by the National Institute of Statistics).

\subsubsection{Cultural and educational influence area}

In delineating the cultural and educational influence area, the option of secondary school students in the adjacent settlements to take high school courses in Focşani city was taken into account. Data series (2003, 2007, 2012 and 2017) were extracted from the records of the Ministry of Education on the admission of high school students to schools in Vrancea County.

It was necessary to extract several data series to identify, on the one hand, the socio-cultural 
attraction capacity of Focşani city during 2003-2017 and, on the other hand, to observe whether the city has a traditional recruitment pool for secondary school students.

The number of secondary school students in the influence area of Focşani city, attracted by high schools in the polarizing city, shows a significant decrease from one year to the next. This is determined by the decrease in the number of young people in the rural settlements included in the influence area of the city. It is also noted that, throughout the analysis period, the cultural and educational influence area of Focșani city is constant, attracting a significant share of students.

The analysis of the map of the cultural and educational influence area for 2003 shows the highest values of secondary school students in the influence area who opted for high schools located in Focşani, even exceeding 100 people (Gugeşti commune). Very high values (between 75-101 people) are specific to only three communes, two of which are located near Focşani city (located in the third ring of settlements: Gugești and Vulturu), plus the Vizantea-Livezi commune, located 45 km away from Focşani (Fig. 10).

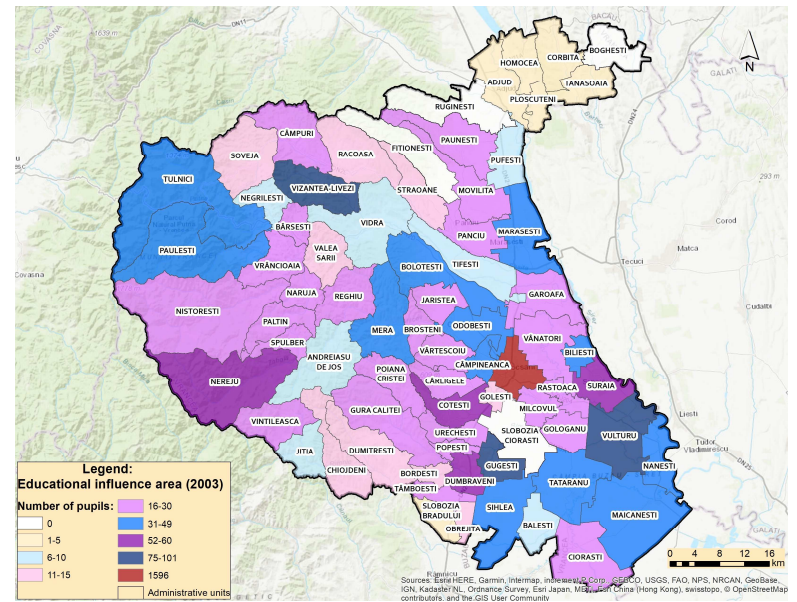

Fig. 10. Cultural and educational influence area of Focşani city (2003) (edited by authors based on data provided by the Ministry of Education).

High number of secondary school students who chose to attend high schools in Focşani (between 52-60 people) are found in three communes located 10-20 km away from the county seat (Coteşti, Dumbrăneni, and Suraia) and Nereju commune, located at a much longer distance $(55 \mathrm{~km})$.

Average values (31-49 persons) are recorded in 12 communes, with a higher concentration in the southern (Tătăranu, Năneşti, Măicăneşti and Sihlea) and central areas of the county (Câmpineanca, Mera, Boloteşti, and Odobeşti), as well as in four other settlements located in the east (Mărășesti and Biliești) and in the north-western part of the county (Tulnici and Păuleşti). Most of the settlements recording values between $16-30$ people have a relatively scarce spatial distribution in the territory. Higher concentration consisting of one town (Panciu) and 26 communes (Cârligele, Vânători, Garoafa, Vrâncioaia, Năruja, etc) was identified in the central, eastern and western parts of the county. Relatively low values (between 11-15 persons and 6-10 persons) are found in 7 and 6 administrative-territorial units, which are randomly distributed within the county. Communes located in the north-eastern part of Vrancea County, and Adjud town, are characterized by the lowest number of secondary school students who opted for high schools located in Focşani. This is explained by the fact that Adjud town has two high schools and attracts a significant number of students from nearby communes. In 2003, the number of secondary school students enrolled in high schools in Focşani was of 3,254 . Half of these students (51\%) were attracted from the influence area. In 2007 , there was a significant decrease of almost half the number of secondary school students compared to 2003, most of them coming from Suraia commune (55 persons). Although with lower values we can note other 5 communes from which 38 to 55 students enrolled in high schools in Focșani city: Vulturu - 49 persons, Gugeşti - 46 persons, Dumbrăveni - 40 persons, Nereju -38 persons (Fig. 11).

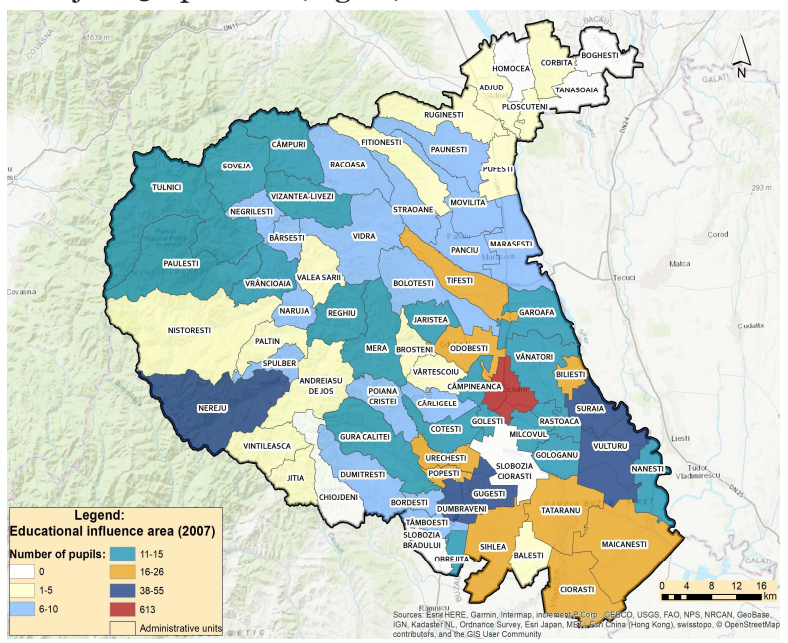

Fig. 11. Cultural and educational influence area of Focşani city (2007) (edited by authors based on data provided by the Ministry of Education).

Compared to 2003, the average values in 2007 are recorded by a smaller number of settlements (9) located in the southern (Urecheşti, Popeşti, Sihlea, Tătăranu, Măicăneşti, and Ciorăşti) or in the centraleastern parts of Vrancea County (the town of Odobești and Bilieşti and Ţifeşti communes).

Numerous communes (19) recorded values ranging from 11-15 students who chose high schools in Focşani. There are two areas of concentration of these settlements: the south-east and north-west of the county (Garoafa, Vânători, Răstoaca, Năneşti, Tulnici, Păuleşti, Soveja, and Vrâncioaia) and the territory near Focşani: Golești, Câmpineanca, and Coteşti. 
A quarter of the total number of communes and small towns in Vrancea County registered low values of secondary school students (between 6-10 persons) who chose to follow high school courses in Focşani, and they are located mostly in the north and north-east of the county (Răcoasa, Păuneşti, Vidra, Năruja, Panciu, and Mărăşești).

Alike the situation registered in 2003, the smallest values (between 1-5 persons were recorded in the north-east, (the town of Adjud and the rural settlements around it) the west (Nistoreşti, Paltin, Andreiaşul de Jos, Jitia) or the central part of the county (Broşteni and Vârteşcoiu).

The socio-cultural attractiveness of Focșani city can be highlighted by the number of high school students it attracted in 2007. During that year, some 1,463 students were enrolled in Focşani high schools; 850 persons of them (representing $58 \%$ of the total number of high school students) came from the influence area. In 2012, the very high and high number of secondary school students are maintained at similar rates to those registered in 2007. They are specific to communes situated in the central and southern parts of the county: Vânători - 54 students, followed by Gugeşti - 50 students, Mera - 49 students, Sihlea - 41 students, Dumbrăveni - 41 students, Suraia, Tătăranu, Măicăneşti, etc (Fig. 12).

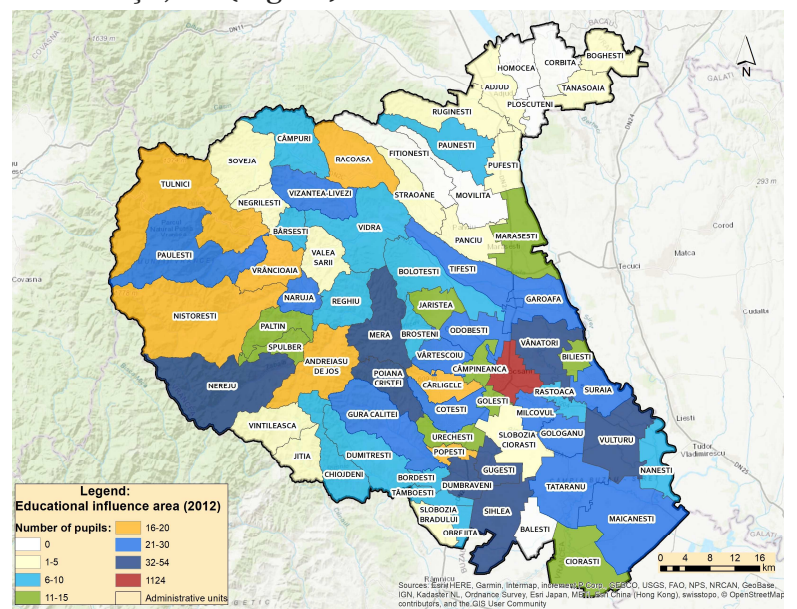

Fig. 12. Cultural and educational influence area of Focșani city (2012) (edited by authors based on data provided by the Ministry of Education).

The average number of secondary school students who chose to attend high school in the county seat is concentrated in the northern and north-western parts of the county (Reghiu, Vidra, Bârsești, etc). In the north-easte, the lowest number is recorded in the area polarized by the town of Adjud. In 2012, in the high schools of Focșani city, 1,660 pupils were educated, out of which more than half (66\%) came from its influence area (1.098 persons). In 2003, Focșani attracted a larger number of students from its influence area compared to 2007 ( 850 persons). In 2017 there is a significant decrease in the number of secondary school students from the influence area who attended high 22 school in Focşani city. The highest value, reaching the threshold of only 43 people, was registered by Gugeşti commune, which is located in the traditional basin of attracting secondary school students. and the only rural settlements registering a high value of this indicator (Fig. 13). There are only four other settlements that recorded relatively high values (27-30 persons), namely three communes (Vulturul, Cotești, and Nereju) and the town of Mărășesti.

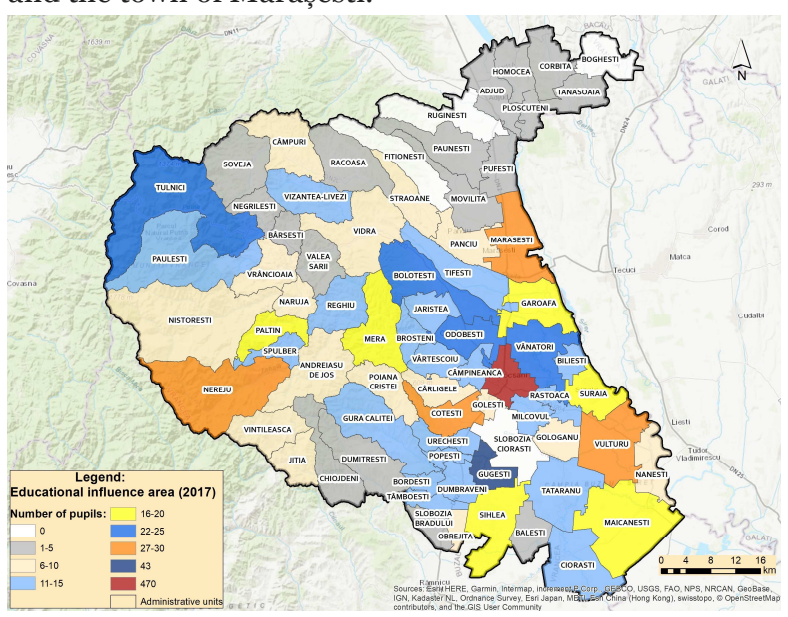

Fig. 13. Cultural and educational influence area of Focșani city (2017) (edited by authors based on data provided by the Ministry of Education).

Values of 20-23 pupils were registered by 19communes s, most of them being concentrated in the first 3 rings of settlements around Focşani (Câmpineanca, Urecheşti, Bilieşti etc.) and which are part of the traditional attraction basin of students. Thise decrease in the number of available pupils is a result of the drop in the share of young population (Fig. 13). Average values were noted in only 6 communes (Suhaia, Sihlea, Măicăneşti, Mera, Garoafa, and Paltin), which are part of the traditional basin but with significantly low number of students compared to 2012. Low values (5-10 persons) and very low values (less than 5 persons) are specific to several communes, mostly concentrated in the northern half and north-east area of Vrancea County. The socio-cultural attractiveness of Focşani city was also maintained at a high level in 2017, when it attracted 784 students from its influence area, representing $62.5 \%$ of the total number of students enrolled in high schools. The number of students choosing high schools in Focşani decreased with the increase of distance (in the west, the limit is also imposed by the difficult access determined by the rough topography). This explains the options of students in Soveja to attend Panciu High School.

We may also note that Focşani city attracted high school students from the neighbouring counties, too, during the analysed period. Although the number is not very high, the socio-cultural attractiveness of the county seat for students from neighbouring counties is noteworthy. Students came mainly from the counties of Galați, Buzău and Brăila (Table 1): 
Table 1. Secondary school students from other counties attracted by Focşani city (source: The Ministry of Education, modified).

\begin{tabular}{l|rrrrr} 
Counties/Years & $\mathbf{2 0 0 3}$ & $\mathbf{2 0 0 7}$ & $\mathbf{2 0 1 2}$ & $\mathbf{2 0 1 7}$ \\
\hline Galați & 8 & 3 & 1 & 2 \\
Buzău & 2 & 2 & 2 & 2 \\
Brăila & 1 & 2 & 1 & 1 \\
Bacău & - & 1 & 1 & - \\
Iași & - & 1 & 1 & - \\
Ialomița & - & - & 1 & - \\
Dâmbovița & 1 & - & - & - \\
Hunedoara & - & 1 & - & - \\
Tulcea & 1 & - & - & - \\
Constanța & 1 & - & - & - \\
Harghita & - & 1 & - & - \\
București & - & 1 & - & - \\
\hline
\end{tabular}

In Focșani, there is a branch of Danubius University of Galaţi, consisting of three faculties, namely: Law, Economic Sciences and Communication and International Relations.

Culturally, Focşani city provides access to the following facilities: Maior Gh. Pastia Theatre, Popular Athenaeum, "Vrancea Country" Folklore Professional Ensemble, the Union Museum (history) and Vrancea Museum (history, archaeology and natural sciences), several churches and religious monuments, and some administrative buildings that seem to be of interest for their architecture, namely the County Court and the Prefecture. The multitude and diversity of cultural and administrative facilities outlines the capacity of polarization of Focşani city on the population living in its area of influence. Also, public health care facilities include two public and one private hospitals. Most of the county's health and social care facilities (over 50\%) are concentrated here, offering diversified services (Integrated Strategy for the City of Focșani, 2016).

\subsubsection{Supply area for agri-food products}

Several areas of supply with vegetables and fruits can be distinguished in the adjacent area Focşani city. The establishment of supply areas with agri-food products was correlated to the natural conditions of the territory that mainly show variety and determine further diversity. The different topography and altitude imposed a mixture of soils and climatic conditions that are directly reflected in the differentiation of agricultural crop areas (Fig. 14).

The already individualized areas, such as the north-west, south-west, and south-east in the influence area include favourable soil and climate conditions and they are able to provide the population of the county seat with fruits and vegetables all year round (e. g. Vidra, Mera, Milcov, Dumbrăveni, and Câmpineanca). Specific agricultural activities have been developed and carried out, such as: tomato production (Câmpineanca andBiliești), eggplants (Biliești), cherries (Movilița), sour cherries (Țifești), plums (Serbești and Vidra), grapes (Câmpineanca and Vârteșcoiu), and berries (Boghești, Dumbrăveni, and Biliești).

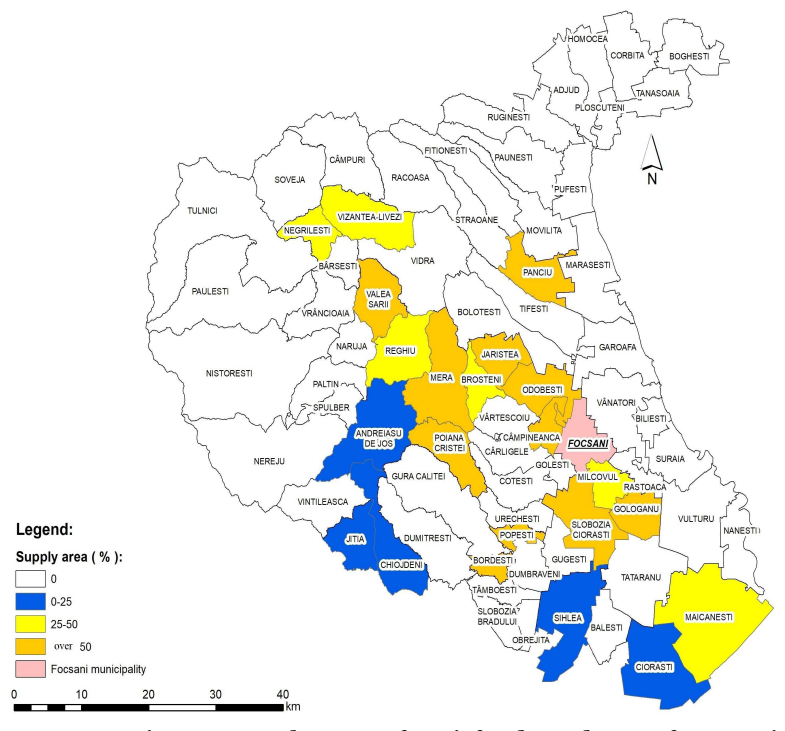

city.

Also, fruit-tree growing is specifically practiced in the following locations: Valea Milcovului, FocşaniSuraia, Vulturu-Tătăranu-Măicănești, Valea Putnei, Panciu, Cotești-Tâmboiești (Coman and Chiţu, 2014). Wine industry is particularly developed in the towns of Odobeşti and Panciu and the commune of Cotești.

\subsection{Individualization of the influence area of Focşani city}

In view of the aforementioned indicators, several types of main influence areas were delimited, based on their intersection. Mathematically transposed, the overlapping of several areas of influence implies the average extension given by the intersection of the influence areas of at least three elements (Ianoş, 1987).

According to the provisions of the national legislation (Law no 351/2001), Focșani city should have an influence area of about 200,000-500,000 inhabitants, a service range of about $60-80 \mathrm{~km}$. Overlapping the five influence areas of the city, however, results in an influence area that covers the entire territory of Vrancea County. The area consists of 72 administrative-territorial units (4 towns and 68 communes), with a population of 390,148 inhabitants (according to the latest demographic data available), and extends over an area of 448,900 hectares (Fig. 15).

Regarding the influence area calculated based on indicators, following the comparative analysis and the quantification of intensity of relationships established between the county seat and settlements in its support area, we learned the following: 
- a primary influence area, where the polarization of the county seat is very high, characterized by intense relationships with the surrounding settlements from several perspectives: economic, administrative, transport, social and cultural (Fig. 15);

- a secondary influence area, in which case the polarization of the county seat extends beyond the border of the attraction area of the towns of Panciu, Mărășeşti, and Adjud. The territorial links established by the county seat with the settlements in this area are quite weak, affected by the presence of other towns with reduced attraction area, as indicated by the number of students atracted from these settlements. A slight decrease in the intensity of economic, social or cultural relationships between Focşani and the other settlements was noted;

- a tertiary influence area, with low-intensity territorial ties in terms of population flows mainly due to less advantageous transport links (long distances and low accessibility). This area is especially important because it represents the support space for recreation and leisure for the population of Focşani city (particularly the mountainous area in the west of Vrancea County). This area has a rich and diverse natural tourism potential: forests cover over $40 \%$ of the county's area (Local Environmental Action Plan, 2012), numerous protected areas, various natural landscapes due to geological diversity, all combined with cultural heritage elements (vernacular architecture, customs and traditions etc.).

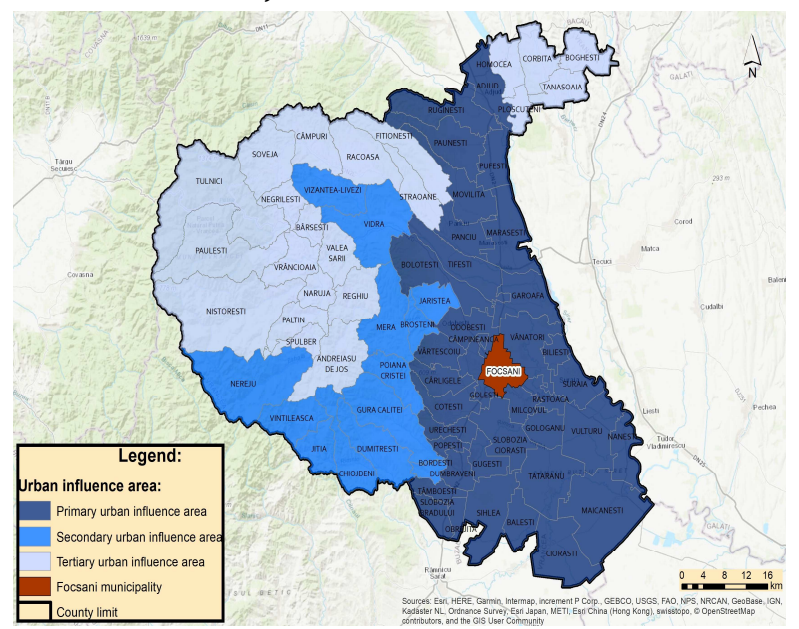

Fig. 15. Influence area of Focșani city.

The influence area of Focşani includes especially the rural areas in close connection with the polarizing city from the economic, functional and spatial perspectives. Still, there are small towns and poorly developed communes within the support area of Focşani city, that, although having some development perspectives sustained by economic and cultural resources (wine-growing area, the tourist road - the Wine Road, vernacular architecture etc.) have not yet come to achieve great results.

\section{CONCLUSIONS}

We believe it is important to identify the urban influence area to reflect the polarizing capacity of a city through the relationships established with the adjacent area. The size of the urban centre and its functional complexity influence the size and degree of development of the influence area. The complex relationships between the city and the polarized area require the selection of several basic criteria to define its influence area. One of the most important criteria is the convergence of transport systems. Transport has always influenced the dynamics of processes related to the changes in territorial planning and development.

The influence area of Focşani city was established based on several criteria and indicators, aiming to highlight the importance of this polarizing city, as second-ranked urban centre at the national level in accordance with the complexity and intensity of the economic, social and cultural relationship (territorial ties) it establishes with the settlements in its predominantly rural adjacent area. The urban system of Vrancea County is relatively unbalanced as a result of the small number of urban centres: the county seat and only 4 other small towns. The analysis of the relationships between the polarizing city and the other territorial administrative units reflects the dominance of political, administrative, economic, demographic and socio-cultural (educational) relationships. In this context, and considering the distribution of transportation system, Focşani city covers (influences) the entire area of Vrancea County. Authors showed the distribution of the degree of polarization of Focşani city according to the intensity of the territorial relationships it establishes with the other urban and rural settlements. Thus, a first area of primary influence includes settlements that recorded the largest flows of human and material resources in the socio-cultural and economic relationships with the county seat. Within the secondary influence area, Focşani city develops different territorial linkages with other settlements which are not affected by the presence of other towns.

The tertiary influence area is characterized by the territorial ties of a lower intensity in terms of the population flows attracted by the economic, social and educational activities, due mainly to the less advantageous transport links (long distances and low accessibility). However, this area has an important role in terms of recreation and leisure for the population of Focşani city (the western mountainous part of Vrancea County). Based on a coherent development and investment strategy in tourism infrastructure on medium and long-term this area could become the support area for recreational activities. Focşani city is supported by a relatively concentric area, which permanently interacts with it and can be defined in terms of the relationships between them. 


\section{REFERENCES}

Ali J., Varshney D. (2012), Spatial modelling of urban growth and urban influence: approach of regional development in developing economy (India). Journal of Urban and Regional Analysis, 4(2), $129-148$. http://www.jurareview.ro/resources/pdf/volume_10_ _spatial_modelling_of_urban_growth_and_urban_inf luence:_approach_of_regional_development_in_devel oping_economy_(india)_abstract.pdf. Accessed on 28.11. 2018.

Allix A. (1922), The geography of fairs: illustrated by Old-World examples. Geographical Review, 12(4), 532569. DOI: https://www.jstor.org/stable/208590. Accessed on 22.12.2018.

Autogara Nord Focșani URL: https://www.autogari.ro/628/autogara_nord_focsani_ _transport_public_sa_/Autogara20522?lang=ro.

Accessed on 20.02.2017

Bański J., Czapiewski K., Górczyńska M. (2016), Impact of the locations of small towns in Mazovia (Poland) on their socio-economic structure and on their role in relation to the neighboring rural areas. Journal of Urban and Regional Analysis, 8(2), 117-131. URL: http://www.jurareview.ro/resources/

pdf/volume_18_impact_of_the_locations_of_small_t owns_in_mazovia_(poland)_on_their_socioeconomic_structure_and_on_their_role_in_relation_t o_the_neighboring_rural_areas_abstract.pdf.

Accessed on 30.2018.

Benedek J. (2016), The role of urban growth poles in regional policy: the Romanian case. Procedia Social and Behavioral Sciences, 223, 285-290, $2^{\text {nd }}$ International Symposium "New Metropolitan perspectives" Strategic planning, spatial planning, economic programs and decision support tools, through the implementation of Horizon/Europe 2020, Reggio Calabria, Italy, 18-20 May 2016. URL: https://ac.elscdn.com/S1877042816304487/1-s2.0-S1877042816 304487-main.pdf?_tid=ac32412b-9859-4899-bb287020361f8a31\&acdnat=1547751241_4dd9eac064e401 845c2376cfa3340252. Accessed on 21.11.2018.

Catană M. C., Baltălungă A. A. (2012), Determination of the area of influence of Ploiești city in the urban system of Prahova County. Annals of Valahia University of Târgovişte. Geographical Series, Tome 12, 1 (2), 24-29. URL: https://fsu.valahia.ro/ images/avutgs/1/2012/201212123.pdf. Accessed on 14.12. 2018.

Cepoiu A.-L. (2009), Rolul activităților industriale în dezvoltarea aşezărilor din spațiul metropolitan al Bucureștilor [The role of industrial activities in the development of settlements fromn the metropolitan area of Bucharest]. Editura Universitară, Bucharest. [Book in Romanian]. ISBN 978-973-749-562-4.

Cîrnu L. (2012), Origini și modele de gestiune ale periurbanizării în SUA, Europa de Vest și Europa
Centrală [Urban sprawl origins and management models in United States, Western and Central Europe] [Article in Romanian]. Analele Asociației Profesionale a Geografilor din România, 3(3), 31-42. URL: http://doccdn.simplesite.com/d/77/a5/2865415323910 56759/af6c1f5e-f95c-4c2c-99a5-3co55c5odd45/

Analele\%2BAPGR\%2B3_2012.pdf. Accessed on 20.12.2018.

Coman M., Chițu E. (coord.) (2014), Zonarea speciilor pomicole în functie de conditiile pedoclimatice şi socio-economice ale României [The zoning of fruit species by soil, climate and socio-economic conditions in Romania], The Institute of Research and Development for Fruit Growing Pitești-Mărăcineni, Editura Invelmultimedia, Otopeni. [Book in Romanian]. ISBN: 978-973-1886-93-0. Accessed on 31.12. 2018.

Cusin F., Lefebvre H., Sigaud T. (2016), The periurbanization issue. A study of growth and diversity in peripheral areas in France. Revue Francaise de Sociologie, 57(4), 641-679. URL: file://C:/Users/georg/Downloads/E_RFS_574_0641. pdf. Accessed on 24.11.2018.

Drăghici C. C. (2012), Activitățile turistice și dezvoltarea integrată în zona de influență a oraşului Râmnicu Vâlcea [Tourist activities and integrated development in the influence area of Râmnicu Vâlcea], Editura Universitară, Bucharest. [Book in Romanian]. ISBN 978-606-591-491-9.

Drăghici C. C., Peptenatu D., Merciu C., Cercleux A. L., Pintilii D. R., Mușat A. (2011), The specificity of the development of local economies from the influence area of the city Râmnicu Valcea. Annals of Valahia University of Târgoviște. Geographical Series, 11, 109-118. URL: https://fsu.valahia.ro/images/avutgs /1/2011/2011111219.pdf. Accessed on 11.03.2017.

Dumitrache L., Zamfir D., Nae M., Simion G., Stoica I. V. (2016), The urban nexus: contradictions and dilemmas of (post)communist (sub)urbanization in Romania. Human Geographies - Journal of Studies and Research in Human Geography, 10(1), 39-58. URL: http://humangeographies.org.ro/articles/101/a_101_3 dumitrache.pdf. Accessed on 20.12.2018

Ghelfi L., Parker T. S. (1997), A county-level measure of urban influence. Rural Development Perspectives, 12(2), 32-41. URL: https://pdfs.semantic scholar.org/5bfo/ecb5c3216b8d18dbe753b616bdfoeba3 73ff.pdf. Accessed on 21.12.2018.

Hama W., Petrişor A. I. (2018), Urbanization and risks: case of Bejaia city in Algeria. Human Geographies - Journal of Studies and Research in Human Geography, 12(1), 97-114. URL: http://human geographies.org.ro/articles/121/a_121_6_petrisor.pdf. Accessed on 29.12.2018.

Ianoş I. (1987), Oraşele şi organizarea spațiului geografic. Studiu de geografie economică asupra teritoriului României [Cities and the organization of the 
geographical area. An economic geography study on the Romanian territory]. R. S. Romania Academic Publishing House, Bucharest. [Book in Romanian].

De Lucca G. (2016), The paradigmatic case of the Metropolitan city of Florence. Procedia Social and Behavioral Sciences, 223, 108-112, $2^{\text {nd }}$ International Symposium "New Metropolitan perspectives" Strategic planning, spatial planning, economic programs and decision support tools, through the implementation of Horizon/Europe 2020, Reggio Calabria, Italy, 18-20 May 2016. URL: https://ac.elscdn.com/S1877042816304001/1-s2.0-S18770428163 04001-main.pdf?_tid=ocf7af58-cao6-417b-9ee427aa8f3515d1\&acdnat $=1547751140 \_$f6cba6cocac2f5073 3cb18fd9bb22e3d. Accessed on 30.11.2018.

Ianoş I., Sîrodoev I., Pascariu G. (2012), Land-use conflicts and environmental policies in two postsocialist urban agglomerations: Bucharest and Chișinău. Carpathian Journal and Environmental Sciences, 7(4), 125-136. URL: file://C:/Users/georg/ Downloads/2012Ianosetal.LUconflicts_CJEES_BaiaMa re.pdf. Accessed on 30.12.2018.

Ianoș I., Sorensen A., Merciu C. (2017), Incoherence of urban planning policy in Bucharest: its potential for land use conflict. Land Use Policy, 60, 101-112. URL: https://www.deepdyve.com/lp/elsevier/ incoherence-ofurban-planning-policy-in-bucharest-its-potential-for-

T2wgphzv16?impressionId=5ac5988c657

52\&i_medium=docview\&i_campaign $=$ recommendations \&i_source=recommendations. Accessed on 20.12.2018.

Ianoș I., Stoian D., Saghin I., Tălângă C., Merciu F. C., Zamfir D., Văidianu N., Schvab A., Cercleux L., Pintilii R., Pascariu G., Iojă C., Peptenatu D., Drăghici C., Braghină C., Stoica I. V. (2014), Bucureşti şi zona sa metropolitană. Privire comparativă cu Sofia şi Atena [Bucharest and its metropolitan area. A comparative view with Sofia and Athens]. Editura Universitară, Bucharest. [Book in Romanian, English]. ISBN 978-606-591-914-3.

Iordan I. (1973), Zona periurbană a Bucureştilor [Periurban area of Bucharest]. Editura Academiei R.S. România, Bucureşti.

Jucu I. S. (2012), Optimizarea spațială la nivel microscalar. Propunerea unui sistem teritorial local viabil cu rol de asigurare a coerenței spațiale la nivelul zonei de influență imediate a municipiului Lugoj [Spatial optimization at micro-scalar level. Proposal for a viable local territorial system to ensure spatial coherence in the inner influence area of Lugoj], Terra, 1-2, Year XLIII (LXIII), 116-122.

Koushik M. M., Soumendu C., Nilanjana D. C. (2015), The Defining Sphere of Urban Influence: The Case of Three Early Urban Centres of Eastern India. Journal of Humanities and Social Science, 20(11), 91100. URL: http://www.iosrjournals.org/iosr-jhss/ papers/Vol2O-issue11/Version-4/No201149110o. pdf. Accessed on 21.12.2018.
Kraft S., Halás M., Vančura M. (2014), The delimitation of urban hinterlands based on transport flows: a case study of regional capitals in the Czech Republic. Moravian Geographical Reports, 1(22), 24-32. URL: https://geography.upol.cz/soubory/lide/halas/ clanky/Kraft,Halas,Vancura-MGR.pdf. Accessed on 14.12.2018.

Kristóf A. (2018), The impact of suburbanization on social differentiation in Hungary: a case study of the Miskolc agglomeration. Geographica Pannonica, 22(3), 176-188. URL: http://www.dgt.uns.ac.rs/pannonica/ papers/volume22_3_2.pdf. Accessed on 21.12.2018.

Law no 351/2001 of approving the national territorial organization plan - section IV - Settlements Network. URL: https://lege5.ro/Gratuit/gmztgobx/legea-nr-3512001-privind-aprobarea-planului-de-amenajare-ateritoriului-national-sectiunea-a-iv-a-reteaua-delocalitati. Accessed on 10.12.2018

Landré M., Håkansson J. (2013), Rule versus interaction function: evaluating regional aggregations of commuting flows in Sweden. EJTIR, 13(1), 1-19. URL: https://d1rkab7tlqy5f1.cloudfront.net/TBM/Over \%2ofaculteit/Afdelingen/Engineering\%2oSystems\%20 and\%20Services/EJTIR/Back\%2oissues/13.1/2013_01 _oo\%2oRule\%20versus\%20Interaction\%2oFunction.p df. Accessed on 20.12.2018.

Lois González R. C., Piñeira Mantiñán M. J., Vives Miró S. (2016), The urban bubble process in Spain: an interpretation from the theory of the circuits of capital. Journal of Urban and Regional Analysis, 8(1), 5-20. URL: http://www.jurareview.ro/resources/ pdf/volume_17_the_urban_bubble_process_in_spain: _an_interpretation_from_the_theory_of_the_circuits _of_capital_abstract.pdf. Accessed on 29.12.2018.

Madzevic M., Apostolovka-Toshevska B., Iliev D. (2013), A process of demographic and economic polarization in the Republic of Macedonia. Geographica Pannonica, 17(2), 37-45. URL: http://www.dgt.uns.ac.rs/pannonica/papers/volume17 _2_2.pdf. Accessed on 30.12.2018.

Merciu G.-L., Braghină C., Muşat N. S. (2012), Utilizarea metodei multicriteriale pentru delimitarea zonei de influenţă a municipiului Reşiţa [Using the multi-criteria method for the delineation of the influence area of Reşita city]. Analele Asociaţiei Profesionale a Geografilor din România, 3, 15-30. URL: http://doccdn.simplesite.com/d/77/a5/2865415323910 56759/af6c1f5e-f95c-4c2c-99a5-3co55c5odd45/

Analele\%2BAPGR\%2B3_2012.pdf. Accessed on 30.11. 2018.

Ministry of Education. URL: www.admitere.edu.ro. Accessed on 11.12.2018.

Modai-Snir T., van Ham (2018), Neighbourhood change and spatial polarization: The roles of increasing inequality and divergent urban development. Cities, 82, 108-118. URL: https://reader.elsevier.com/reader /sd/pii/So264275117314075?token=69B571A1159D119 
431753DC57D830FDoCB19848EA9B5EDADE4A6F5A3 1F45B28F67B7AD52A412BEDD64F1A8D3A94C165E. Accessed on 28.12.2018.

Mutabdzija G. (2016), Sarajevo-Romanija region: a fluid space between the rural and urban. European Countryside, 3, 296-303. DOI: https://doi.org/10. 1515/euco-2016-0021. Accessed on 21.12.2018.

National Institute of Statistics, the Tempo online database.

Nicula A.-S., Stoica M. S., Ilovan O.-R. (2017), The cultural-historical and political spheres of influence of Alba Iulia. Transylvanian Review, 27(suppl. 2), 299-315. URL: http://www.centruldestudii transilvane.ro/ Document_Files/Review\%202015\%20-\%202035/

oooo0770/hg536_NicolaIlovan.pdf. Accessed on 10.12. 2018

Niță M. R., Năstase I. I., Badiu D.-L., Onose D.A., Gavrilidis A.-A. (2018), Evaluating urban forests connectivity in relation to urban functions in Romanian cities. Carpathian Journal and Environmental Sciences, 13(1), 291-299. URL: file:///C:/Users/georg/ Downloads/Nita-Nastase\%2O (2).pdf. Accessed on 20.12.2018.

Onea D. (2016), Optimizarea spațială a sistemului teritorial în zona de polarizare apropiată a municipiului Caransebeș [Spatial optimization of territorial system in Proximity Area of Caransebeș Municipality]. The Annals of the Geographers' Professional Association of Romania, 7, 31-39. URL:http://www.apgranale.com/434341649. Accessed on 21.12. 2018.

Peptenatu D., Merciu C., Merciu G., Drăghici C., Cercleux L. (2012), Specific features of environment risk management in emerging territorial structures. Carpathian Journal of Earth and Environmental Sciences, 7(2), 135-143.

Pintilii R. D. (2008), Turismul și rolul său în dezvoltarea integrată a zonei de influență a Municipiului București [Tourism and its role in the integrated development of the influence area of Bucharest]. Editura Universitară, Bucharest. [Book in Romanian]. ISBN 978-973-749-597-6.

Petrişor A.-I. (2012), Land cover and land use analysis of urban growth in Romania. Human Geographies - Journal of Studies and Research in Human Geography, 6(1) 47-51. URL: http://human geographies.org.ro/articles/61/6_1_12_5_petrisor.pdf. Accessed on: 29.12.2018.

Petrişor A.-I., Ianoş I., Tălângă C. (2010), Land cover and use changes focused on the urbanization processes in Romania. Environmental Engineering and Management Journal, 9(6), 765-771. URL: http://www.eemj.icpm.tuiasi.ro/pdfs/vol9/no6/2_52_ Petrisor_10.pdf. Accessed on 30.12.2018.

Primăria Municipiului Focşani (2016), Integrated Strategy for Sustainable Development of Focşani City, 2014-2020. URL: http://www.focsani.info/fisiere/ pagini_fisiere/strategie.pdf. Accessed on 01.01. 2019.
Randolph B., Tice A. (2017), Relocating Disadvantage in Five Australian Cities: Socio-spatial Polarisation under Neo-liberalism. Urban Policy and Research, 35(2), 103-121. DOI: https://doi.org/ 10.1080/08111146.2016.1221337. Accessed on 30.11. 2018.

Rusu R. (2007), Organizarea spațiului geografic în Banat [Organizing the geographical space in Banat]. Editura Mirton, Timişoara. [Book in Romanian]. ISBN978-973-52-0201-9. URL: file:///C:/Users/georg/ Downloads/Raularian-Rusu_organizarea-spatiuluigeografic-in-Banat-2007\%20(2).pdf. Accessed on 21.12.2018.

Rusu R., Man T. (2006), The Reilly-Converse urban attraction model applied to Banat using GIS. Geographica Technica, 1, 175-180. URL: http://technicalgeography.org/pdf/1_2006/gt_1_2006 .pdf. Accessed on 18.12.2018.

Salvati L. (2018), Population structure and economic cycles in Greece: a multidimensional regional analysis (1988-2016). Journal of Urban and Regional Analysis, 10(1), 61-78. URL: http://www.jurareview.ro/resources /pdf/volume_25_population_structure_and_economic _cycles_in_greece:_a_multidimensional_regional_ana lysis_(1988-2016)_abstract.pdf. Accessed on 31.12.2018.

Scott A., Storper M. (2015), The nature of cities: the scope and limits of urban theory. International Journal of Urban and Regional Research, 39(1), 1-15. DOI: https://doi.org/10.1111/1468-2427.12134

Servillo L., Atkinson R., Smith I., Russo A., Sýkora L., Demazière C., Hamdouch A. (2014), TOWN, small and medium sized towns in their functional territorial context, Final Report, ESPON. URL: file:///C:/Users/georg/Downloads/TOWN_Final _Report_061114.pdf. Accessed on 30.11.2018

Smailes A. E. (1947), The analysis and delimitation of urban fields. Geography, 32(4) 151-161 DOI: https://www.jstor.org/stable/40562608. Accessed on 22.12.2018.

Sobolev A. (2015), Structural and functional characteristics of the spatial development of rural and urban areas in the Northwestern economic district. Baltic region., 23, 108-119. URL: https://www.ssoar. info/ssoar/ bitstream/handle/document/51319/ssoar-balticreg-2015-1sobolev-Structural_and_Functional_

Characteristics_of.pdf?sequence=1. Accessed on 27.12.2018.

Surd V. (2003), Geografia așezărilor [Geography of settlements], Editura Presa Universitară Clujeană, ClujNapoca. [Book in Romanian]. ISBN 973-610-051-0.

Surd V., Păcurar B.-N. (2010), „The Frontier” defining the urban influence area. Studia Universitatis Babeș-Bolyai, Geographia, 2, 161-174. URL: http://studia.ubbcluj.ro/download/pdf/513.pdf.

Accessed on 16.12. 2018.

Surd V., Kantor C.-M., Păcurar B.-N. (2015), Peripheral cores or central peripheries? Journal of 
Settlements and Spatial Planning, 6(4), 95-105. URL: http://geografie.ubbcluj.ro/ccau/jssp/arhiva_si4_2015 /o3JSSPSI042015.pdf. Accessed on 29.11. 2018.

Tănasă M. (1998), The social and cultural area of influence in Botoșani municipality. The Geographical Essays "Dimitrie Cantemir", 17-18, 221-228.

Van Cleef E. (1941), Hinterland and Umland. Geographical Review, 31(2), 308-311, DOI: https://www.jstor.org/stable/210211 Accessed on 22.12.2018.

Vasárus G., Bajmócy P., Lennert J. (2018), In the shadow of the city: demographic processes and emerging conflicts in the rural-urban fringe of the Hungarian agglomerations. Geographica Pannonica, 22(1), 14-29. URL: http://www.dgt.uns.ac.rs/ pannonica/papers/volume22_1_2.pdf. Accessed on 21.12.2018.

Verma S., Chatterjee A., Mandal N. R. (2017), Analysing Urban Sprawl and Shifting of Urban Growth Centre of Bengaluru City, India using Shannon's Entropy Method. Journal of Settlements and Spatial Planning, 8(2), 89-98. DOI: https://doi.org/10.24193/JSSP.2017.2.02. Accessed on 30.12.2018.

Viganò P., Arnsperger C., Barcelloni M., CogatoLanza E., Cavalieri C. (2017), Rethinking urban form: Switzerland as "horizontal metropolis". Urban Planning, 2(1), 88-99. URL: https://www. cogitatiopress.com/urbanplanning/article/view/871/87 1. Accessed on 30.12.2018.

Vlad Şandru M.-I., Iațu C., Şandru D. C., Cimbru D. G. (2017), Approaching land cover-land use changes using statistical data validation for urban policies improvement. Journal of Settlements and Spatial Planning, 8(2), 119-129. DOI: https://doi.org/ 10.24193/JSSP.2017.2.05. Accessed on 01.01.2019.

Vojkan G. (2013), Comparative analysis of different methods and obtained results for the delineation of functional urban areas. Spatium International Review, 29, 8-15. URl: https://scindeks-clanci.ceon.rs/data/ 018.
pdf/1450-569X/2013/1450-569X1329008G.pdf.

Accessed on 16.12.2018.

Walks R. A. (2007), The boundaries of suburban discontent? Urban definitions and neighborhood political effects. The Canadian Geographer, 51(2), 160185. URL: http://neighbourhoodchange.ca/wpcontent/uploads/2011/o6/Walks-2007-Surburbs-and-

Neighbourhood-Political-Effects.pdf. Accessed on 27.12.2018.

Wang F. (2001), Regional density functions and growth patterns in major plains of China, 1982-1990. Papers in Regional Science, 80, 231-240, Wiley Publishing Press, USA. URL: https://www.researchgate.net/publication/225543918_ Regional_density_functions_and_growth_patterns_in _major_plains_of_China_1982-1990/download.

Accessed on 17.12.2018.

Wang H., Deng Y., Tian E., Wang K. (2014), A comparative study of methods for defining sphere of urban influence: a case study on Central China. Chin. Geogra. Sci., 24(6), 751-762. DOI: https://doi.org/ 10.1007/s11769-014-0678-1. Accessed on 20.12.2018.

Yao Y., Lu Y., Wang G., Dong Y., Wang H. (2018), Relations between global city connectivity of the primary city and the size national economy. Journal of Urban and Regional Analysis, 10(1), 5-23. URL: http://www.jurareview.ro/resources/pdf/volume

_25_relations_between_global_city_connectivity_of_t he_primary_city_and_the_size_national_economy_a bstract.pdf. Accessed on 21.12.2018.

Zitti M., Ferrara C., Perini L., Carlucci M., Salvati L. (2015), Long-term urban growth and land use efficiency in Southern Europe: implications for sustainable land management. Sustainability, 7, 33593385. URL: https://www.mdpi.com/2071-1050/7/3/ 3359/htm. Accessed on 16.12. 2018.

Živanović Z., Tošić B. (2017), Defining urban regions in Serbia. Geographica Pannonica, 21(2), 85-95. URL: http://www.dgt.uns.ac.rs/pannonica/papers /volume21_2_2.pdf. Accessed on 31.12.2 